\title{
ANALISIS DAYA SAING EKSPOR KOPI INDONESIA DAN VIETNAM DI PASAR ASEAN 5
}

\section{COMPETITIVENESS ANALYSIS OF INDONESIAN AND VIETNAM COFFEE EXPORT IN ASEAN 5 MARKET}

\author{
Fadhlan Zuhdi ${ }^{*}$, Suharno ${ }^{2}$ \\ Departemen Agribisnis, Fakultas Ekonomi dan Manajemen, Institut Pertanian Bogor \\ Received: 29th February 2016; Revised: 22th March 2016; Accepted: 24th March 2016
}

\begin{abstract}
ABSTRAK
Selama 14 tahun terakhir, ekspor kopi Indonesia dan Vietnam terus mengalami pertumbuhan khususnya pada jenis kopi HS 090111 (Coffee, not roasted, not decaffeinated) ke pasar ASEAN 5. Pertumbuhan tersebut didasari pada terus meningkatnya kuantitas serta nilai ekspor kopi Indonesia dan juga Vietnam dalam beberapa tahun terakhir. Diadakannya Asean Economic Community (AEC) pada awal tahun 2016 menstimulus eksportir kopi seperti Indonesia untuk tetap menjaga kuantitas ekspornya ke ASEAN 5 sehingga diperlukan sebuah analisa terkait daya saing produk kopi Indonesia di pasar ASEAN 5.Untuk mengetahui sejauh mana ekspor kopi Indonesia dan Vietnam mampu berdaya saing di pasar ASEAN 5, dilakukan analisis RCA (Revealed Comaparative Advantage) dan untuk mengetahui apakah suatu produk dalam performa yang dinamis atau tidak digunakan alat analisis EPD (Export ProductDynamics). Hasil analisis menunjukkan bahwa ekspor kopi Indonesia dan Vietnam di pasar ASEAN 5 memiliki daya saing dengan Indonesia memiliki nilai rata-rata RCA sebesar 10,16 dan Vietnam sebesar 53,44. Hal tersebut juga menunjukkan bahwa ekspor kopi Vietnam lebih memiliki daya saing jika dibandingkan ekspor kopi Indonesia. Sedangkan hasil analisis EPD menunjukkan bahwa perdagangan kopi Indonesia maupun Vietnam berada pada kuadran rising star yang berarti bahwa kinerja perdagangan ekspor berjalan cepat dan dinamis dimana tingkat pertumbuhan ekspor kopi Indonesia terus meningkat seiring dengan meningkatnya pangsa ekspor di ASEAN 5.Pemerintah diharapkan mampu untuk meningkatkan ekspor kopi Indonesia ke pasar ASEAN 5 mengingat terus bertumbuhnya permintaan kopi dari pasar tersebut sehingga perlu diberlakukan sebuah kebijakan taktis yang mampu menstimulus para petani untuk memproduksi kopi secara lebih efisien.
\end{abstract}

Kata kunci: ASEAN; ekspor; kopi; daya saing; RCA

\section{ABSTRACT}

Last 14 years ago, Indonesian and Vietnam coffee export continued to grow especially on the type of coffee with HS number 090111 (Coffee, not roasted, not decaffeinated) to ASEAN 5 market. The growth based on increasing of number in quantity and number in coffee export by Indonesia and Vietnam in recent years. Holding of the Asean Economic Community (AEC) in early 2016 was to stimulate coffee exporters such as Indonesia to be able to maintain the quantity of its exports to ASEAN 5 and necessitating an analysis related to the competitiveness of Indonesian coffee products in the ASEAN markets 5. Whereas, to see what extent the Indonesia and Vietnam coffee export capable competitive in ASEAN 5 market RCA (Revealed Comparative Advantage) analysis used, and to see or identify product in a dynamic performance or not, EPD (Export Product Dynamics) analysis is used. The result of RCA analysis show that Indonesian and Vietnam coffee export in ASEAN 5 market are competitive. Based one the average value of export, Indonesia has 10,16 of RCA and Vietnam has 53,44 of RCA. It also show that Vietnam coffee export more competitive than Indonesia. Moreover, the result of EPD analysis show that the trading of Indonesian coffee and Vietnam are in rising star quadrant which mean that the performance of export running smoothy and dynamic where the growth of Indonesia coffee continues to rise concomitant with the increasing the market share of export in ASEAN 5 market.The government is expected to improve the value of Indonesian coffee export to ASEAN 5 market given the continued growth of demand from ASEAN 5 market, so required the tactical policy which can stimulate farmers to produce coffee more efficiently.

Keywords: ASEAN; export; coffee; competitiveness; RCA 


\section{Pendahuluan}

Semakin terbukanya setiap negara dalam melakukan perdagangan mendorong terciptanya arus globalisasi yang semakin deras. Menghadapi kenyataan ini, Indonesia sebagai negara yang menganut sistem perekonomian terbuka harus dapat mengantisipasi dan memanfaatkan situasi sehingga mendapatkan manfaat yang maksimal. Negara-negara di dunia dalam perekonomian terbuka sangat mengandalkan ekspor dalam hal peningkatan perekonomian. Hal ini dikarenakan kegiatan ekspor akan mempengaruhi laju perekonomian di dalam negeri, dimana dengan semakin tingginya ekspor maka akan memperbaiki neraca perdagangan Indonesia dan akan meningkatkan peluang bagi lapangan pekerjaan baru.

Secara garis besar, untuk meningkatkan ekspor maka yang dapat dilakukan adalah memaksimalkan segala macam potensi yang ada dari berbagai macam sektor. Ekspor Indonesia ditopang oleh dua jenis sektor utama yaitu migas dan non migas. Pada sektor migas, Indonesia memiliki keunggulan dalam hal mengekspor gas alam dikarenakan Indonesia memiliki stockgas alam yang melimpah. Pada sektor non migas, Indonesia memiliki berbagai macam komoditas yang diunggulkan di dunia internasional seperti kelapa sawit, karet, produk tekstil, elektronik maupun otomotif. Saat ini, pemerintah Indonesia memfokuskan untuk meningkatkan ekspor di sektor non migas yang termasuk didalamnya sektor perkebunan. Hal ini dikarenakan ekspor Indonesia dalam sektor migas dalam beberapa tahun ini mengalami defisit.

Salah satu tanaman perkebunan yang menjadi komoditas ekspor yaitu tanaman kopi dan Indonesia merupakan salah satu negara produsen ekspor kopi terbesar ketigadi dunia. Berdasarkan data statistik International Coffee Organization (ICO), Indonesia menempati urutan terbesar ketiga di dunia dibawah Brazil dan Vietnam sejak tahun 2009, bahkan saat ini, ekspor kopi Indonesia mencapai 1.150 .000 ton atau meningkat sebesar $71.1 \%$ dari tahun sebelumnya (ICO, 2015). Tujuan ekspor kopi Indonesia sendiri tersebar ke banyak negara di dunia. Hal ini menunjukkan bahwa kopi Indonesia telah mendunia sehingga banyak

*Penulis Korespondensi.

E-mail: fadhlanzuhdi21@gmail.com

Telp: 082244525492 peminat dari luar negeri yang ingin mengonsumsi kopi Indonesia. Saat ini, pengimpor kopi Indonesia terbesar di dunia adalah Eropa Amerika diikuti oleh Amerika Serikat, Jepang dan ASEAN. Pada tahun 2013, sebesar 17,6 \% dari total ekspor kopi Indonesia telah diekspor ke Amerika Serikat, sebesar 33,9 \% diekspor ke Eropa, 8,9 \% diekspor ke Jepang dan sebesar $15,4 \%$ telah diekspor ke ASEAN, dengan demikian dapat terlihat bahwa nilai ekspor kopi Indonesia sangat besar untuk Eropa dan diikuti oleh Amerika Serikat, ASEAN dan Jepang. Namun demikian, pangsa pasar kopi Indonesia di negara tersebut tidaklah sebanding dengan besarnya nilai ekspor kopi Indonesia. Pada tahun yang sama, pangsa pasar kopi Indonesia di Eropa hanya sebesar $1 \%$, Amerika Serikat hanya sebesar 3,8 \%, dan sebesar 6,4 \% di Jepang. Sedangkan untuk pangsa pasar kopi Indonesia di ASEAN mencapai $36 \%$ (Trade Map, 2015).

Berdasarkan data tersebut, dapat dilihat bahwa pasar ASEAN memiliki potensi yang sangat tinggi khususnya ke negara-negara yang tergabung dalam ASEAN 5 (Filipina, Malaysia, Singapura, Thailand dan Vietnam) karena memiliki nilai ekspor yang tinggi dibandingkan dengan negara ASEAN lainnya. Diberlakukannya AEC di akhir tahun 2015 secara tidak langsung mewajibkan setiap anggota ASEAN harus mampu bersaing terutama dalam hal perekonomian, dan yang termasuk indikator untuk mendukung hal tersebut adalah dengan melakukan ekspor. AEC menstimulus negaranegara di ASEANuntuk melakukan persaingan secara terbuka dengan negara-negara lainnya di Asia Tenggara dan memperbanyak eskpor merupakan salah satu cara bagi Indonesia terlibat dalam persaingan tersebut.

Peningkatan daya saing ekspor kopi Indonesia menjadi salah satu elemen yang penting jika produk kopi Indonesia ingin tetap eksis di ASEAN, mengingat Vietnam yang juga merupakan anggota ASEAN memiliki nilai ekspor kopi yang sangat tinggi jika dibandingkan dengan Indonesia. Maka sudah selayaknya pemerintah Indonesia untuk melakukan evaluasi dan pembenahan untuk menyambut AEC dan melakukan peningkatan dalam hal daya saing produk kopi. Hal tersebut diperlukan karena ASEAN merupakan salah satu pasar potensial bagi Indonesia dalam melakukan ekspor kopi.

Kopi merupkan produk ekspor Indonesia yang memiliki potensi tinggi dalam hal ekspor. Hal tersebut dapat dilihat dari trend ekspor kopi yang meningkat di setiap tahunnya khususnya 
produk kopi dengan HS 090111 (Coffee, not roasted, not decaffeinated). Oleh sebab itu, peningkatakan ekspor diharapkan mampu meningkatkan daya saing kopi khususnya di pasar ASEAN terlebih di era AEC seperti sekarang ini. Penelitian Hadi dan Mardianto (2004) yang berjudul analisis komparasi daya saing produk ekspor pertanian antar negara ASEAN dalam era perdagangan bebas AFTA, menyatakan bahwa daya saing ekspor Indonesia pada periode 1997-1999 paling kuat di antara negara-negara ASEAN, tetapi pada periode 19992001 melemah dan kalah dari Filipina dan Thailand. Menurunnya tingkat daya saing suatu produk di suatu pasar dapat di respon dengan beberapa cara seperti yang telah dijelaskan pada penelitian Ragimun (2012) yang telah mampu menjelaskan bahwa perlu adanya peningkatan daya saing dan salah satu caranya adalah dengan diberlakukannyakebijakan fiskal berupa penerapan bea keluar berjenjang, subsidi ke petani, perbaikan infrastruktur serta riset dan pengembangan nasional. Dalam penelitian ini, kondisi daya saing kopi Vietnam yang merupakan pesaing Indonesia dalam hal ekspor kopi juga disertakan sebagai bahan perbandingan mengingat bahwa sejauh ini Indonesia dan Vietnam merupakan tiga besar pengekspor kopi terbesar di dunia dan sama-sama berasal dari Asia Tenggara. Pada kenyataannya, Indonesia tertinggal jauh oleh Vietnam dalam segi ekspor kopi baik ke dunia umumnya maupun ke ASEAN khususnya. Oleh sebab itu, perlu diketahui sejauh mana ekspor kopi Indonesia memiliki daya saing dan apakah perdagangan yang dilakukan sudah berjalan secara dinamis atau tidak.

\section{Metode Penelitian}

\subsection{Ruang Lingkup Penelitian}

Ruang lingkup penelitian ini dibatasi oleh arus perdagangan Indonesia dan anggota ASEAN-5. Negara-negara tersebut adalah Malaysia, Filipina, Singapura, Thailand dan Vietnam. Komoditas yang akan dijadikan objek dalam penelitian ini adalah komoditas kopi dengan HS 6 digit yaitu 090111 (Coffee, not roasted, not decaffeinated).

\subsection{Jenis dan Sumber Data}

Data yang akan digunakan dalam penelitian ini adalah data sekunder yang diperoleh dari berbagai macam sumber. Data mengenai aliran perdagangan seperti data ekspor dan impor akan diperoleh dari COMTRADE.
Sedangkan data komoditi yang digunakan adalah komoditi yang menggunakan kode HS 6 digit.

\subsection{Metode Analisis}

Metode analisis yang digunakan dalam penelitian ini terbagi menjadi dua metode yaitu metode analisis deskriptif dan kuantitatif.Metode analisis secara deskriptif digunakan untuk menganilisis hal-hal yang terkait dengan kinerja perdagangan Indonesia dan potensi ekonomi negara-negara yang menjadi tujuan ekspor kopi Indonesia. Sedangkan metode analisis secara kuantitatif menggunakan empat alat analisis yaitu Revealed Comparative Advantage (RCA) dan Export Product Dynamics (EPD).

\section{a. Revealed Comparative Advantage (RCA)}

RCA merupakan salah satu metode pengukuran yang berbentuk dinamis. Hal tersebut didukung dengan pernyataan Basri dan Munandar (2010) yang menyatakan bahwa RCA merupakan salah satu metode yang dinamis dan mampu digunakan untuk melakukan analisis daya saing. RCA digunakan dalam banyak penelitian untuk mengukur perubahan keunggulan komparatif suatu bangsa dalam produk, kelompok produk atau industri (UNIDO 1986; Parry 1975; Hillman 1980; Aquino 1981; Crafts and Thomas 1986; Marchese and De Simone 1989; Rana 1990; Yeats 1985; van Hulst et al 1991; Lee 1995; Lim 1997; Richardson et al 1997; Laursen 1998; Yang 1999; Li and Bender 2002). Konsep dari RCA itu sendiri merupakan rasio antara pangsa pasar dari sebuah produk suatu negara di dalam pasar dunia, dengan pangsa ekspor dari suatu negara terhadap total ekspor dunia. Secara matematis, RCA dapat dihitung menggunakan rumus seperti berikut:

RCAij $=\frac{X i k / X i}{X a k / X a}$

Keterangan:

Xik : Nilai ekspor komoditi $\mathrm{k}$ Indonesia ke ASEAN

$\mathrm{Xi}$ : Nilai total ekspor Indonesia ke ASEAN

Xak : Nilai ekpor komoditi $\mathrm{k}$ dunia ke ASEAN

Xa : Nilai total ekspor dunia ke ASEAN

Adapun indikator yang digunkan untuk untuk menghitung nilai RCA index adalah yaitu jika nilai RCA index $>1$, maka terdapat keunggulan komparatif terhadap suatu produk dan jika nilai RCA index < 1 , maka tidak terdapat keunggulan komparatif terhadap suatu produk. 
Semakin tinggi nilai RCA maka semakin tinggi suatu komoditi memiliki daya saing.

\section{b. Export Product Dynamics (EPD)}

Analisis Export Product Dynamics (EPD) digunakan untuk mengetahui atau mengidentifikasi daya saing suatu produk serta untuk mengetahui apakah suatu produk dalam performa yang dinamis atau tidak. Meskipun tidak semua produk memiliki nilai ekspor yang tinggi, bukan berarti produk tersebut tidak memiliki daya saing.

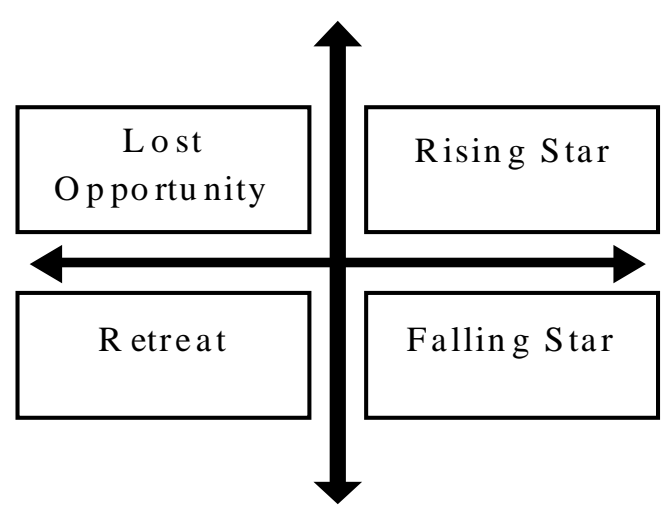

Gambar 1. Daya Tarik Pasar Dan Kekuatan Bisnis Dalam EPD (Esterhuizen, 2006)

Suatu produk yang memiliki pertumbuhan nilai ekspor melebihi nilai rata-rata ekspor secara kontinyu, maka produk tersebut produk tersebut bisa menjadi sumber pendapatan yang besar bagi suatu negara sehingga dapat dikatakan bahwa produk tersebut memiliki daya saing. Berdasarkan penelitian Esterhuizen (2006), matriks posisi dikategorikan menjadi empat kategori yaitu rising star, falling star, lost opportunity dan retreat.

Gambar 1. Menggambarkan empat kategori umum dalam ekspor (berdasarkan posisi pangsa pasar). Rising star menggambarkan posisi pasar tertinggi atau dapat dikatakan pasar yang paling ideal. Lost opportunity merupakan kondisi dimana pasar mengalami penurunan daya saing sehingga produk yang dihasilkan di suatu negara kehilangan kesempatan untuk menjangkau ekspor di pasar internasional.

Falling star merupakan kondisi yang tidak diharapkan oleh suatu negara (sama dengan kondisi lost opportunity), namun kondisi falling star tidak seburuk kondisi lost opportunity karena pada kondisi ini masih terdapat peningkatan pangsa pasar meskipun tidak terjadi untuk produk barang yang dinamis. Retreat merupakan kondisi dimana keberadaan suatu produk tidak lagi diingninkan oleh pasar.Secara matematis, untuk menghitung pangsa ekspor suatu negara (negara i) dan pangsa pasar produk (produkn) dalam sebuah perdagangan dunia adalah sebagai berikut: Sumbu $\quad \mathrm{X} \quad: \begin{gathered}\text { Pertumbuhan pangsa ekspor } \\ \text { Indonesia (\%) }\end{gathered}$

$\frac{\sum_{t=1}^{t}\left(\frac{X i v j}{W i v j}\right)_{t} x 100 \%-\sum_{t=1}^{t}\left(\frac{X i v j}{W i v j}\right)_{t-1} x 100 \%}{T}$

Sumbu Y : Pertumbuhan pangsa pasar produk $\mathrm{n}=$

$\frac{\sum_{t=1}^{t}\left(\frac{X i v t}{W t}\right)_{t} x 100 \%-\sum_{t=1}^{t}\left(\frac{X i v t}{W t}\right)_{t-1} x 100 \%}{T}$

Keterangan:

Xivj :Nilai ekspor komoditi j dari Indonesia/Vietnam ke negara i

Xivt :Total nilai ekspor negara Indonesia/Vietnam ke dunia

Wivj : Nilai ekspor komoditi j dunia ke negara Indonesia/Vietnam

Wt : Nilai ekspor total dunia

$\mathrm{t} \quad$ : Tahun ke-t

t-1 : Tahun sebelumnya

$\mathrm{T} \quad$ : Jumlah tahun analisis

\section{Hasil dan Pembahasan}

\subsection{Potensi Ekonomi ASEAN}

ASEAN (Association of Southeast Asian Nations) merupakan sebuah organisasi yang beranggotakan negara-negara di Asia Tenggara dan terbentuk pada tahun 1967 di Bangkok, Thailand. Sejak berdiri, ASEAN telah mengalami transformasi anggota, mulanya ASEAN hanya beranggotakan lima negara saja yaitu Filipina, Indonesia, Malaysia, Singapura dan Thailand. Namun, pada tahun 1984, Brunei Darussalam bergabung dengan ASEAN dan diikuti oleh bergabungnya Vietnam pada tahun 1995, Laos dan Myanmar pada tahun 1997 dan yang terakhir adalah Kamboja pada tahun 1998. Saat ini, ASEAN terdiri dari sepuluh negara yang menjadi anggota resmi, sedangkan negara seperti Timor Leste dan Papua New Guinea menjadi negara observers.

Secara statistik, ASEAN memiliki penduduk sekitar 622 juta jiwa atau yang terbesar ketiga di dunia setelah China dan India dan apabila ditinjau dari segi ekonomi, perdagangan ASEAN telah mencapai US\$2,5 miliar atau naik 
sebesar US\$ 1 miliar sejak tahun 2007 (Sekretariat ASEAN, 2015). Total PDB ASEAN terus meningkat dimana pada tahun 2014 PDB ASEAN (tidak termasuk Myanmar) telah mencapai US\$ 6,2 triliun atau sekitar 5,97 \% dari total PDB dunia sedangkan total PDB ASEAN (tidak termasuk Myanmar) tahun 2007 sebesar US\$ 4 triliun atau sekitar 5,32\%. Namun demikian, PDB ASEAN hanya didominasi oleh 2 negara saja yaitu Indonesia dan Thailand, dimana kedua negara tersebut menyumbang PDB ASEAN sebesar $59,9 \%$ dari total keseluruhan PDB ASEAN pada tahun 2007 dan sebesar 59,6 $\%$ pada tahun 2014.

Semakin tinggi nilai PDB suatu negara secara teori mencerminkan bahwa semakin besar pula negara tersebut untuk menarik arus investasi. Peningkatan arus investasi tersebut juga akan merubah tingkat pendapatan negara tersebut dan secara otomatis dapat meningkatkan daya beli masyarakatnya. Namun hal tersebut tidak selaras apabila dilihat dari nilai GDP per kapita negara-negara ASEAN yang juga terdapat ketimpangan meskipun dengan formasi yang berbeda.

Berdasarkan data pada Gambar 2. dapat diketahui bahwa Singapura memiliki nilai GDP per kapita tertinggi diantara nagera ASEAN lainnya sejak tahun 2004 hingga 2014 dan diikuti oleh Brunei Darussalam di tempat kedua dan Malaysia di tempat ketiga. Pada tahun 2014, Singapura memiliki pendapatan per kapita sebesar US\$ 56.284 dan berbanding jauh dengan yang dimiliki oleh Kamboja yang hanya sebesar US\$ 1.094. Hal tersebut mengindikasikan bahwa terjadi ketimpangan yang sangat tinggi di antara negara-negara ASEAN dalam hal pendapatan per kapita, meskipun rata-rata pendapatan per kapita negara ASEAN pada tahun 2014 mencapai US\$ 12.705 namun hal itu terjadi dikarenakan pendapatan per kapita Singapura dan Brunei Darussalam yang terlampau besar.

Dari segi perdagangan, terjadi dinamika ekspor dan impor barang maupun jasa diantara negara ASEAN. Menurut laporan tahunan ASEAN tahun 2014, rata-rata pertumbuhan ekspor negara ASEAN sebesar $1,7 \%$ dan ratarata pertumbuhan impor negara ASEAN sebesar $0,3 \%$. Jika dibandingkan dengan tahun sebelumnya, maka rata-rata perumbuhan ekspor negara ASEAN mengalami peningkatan dimana pada tahun 2013, rata-rata pertumbuhan ekspor negara ASEAN hanya sebesar $1,3 \%$ sedangkan rata-rata pertumbuhan impor negara ASEAN mengalami penurunan dimana pada tahun 2013 rata-rata pertumbuhan impor negara ASEAN mencapai $1,5 \%$. Hal tersebut mengindikasikan bahwa negara-negara ASEAN telah mendorong untuk melakukan ekspor lebih banyak daripada melakukan impor dan tentu saja hal ini menjadi semakin baik untuk iklim perdagangan bagi negara-negara ASEAN. Berikut adalah persentase ekspor dan impor negara ASEAN pada tahun 2013.

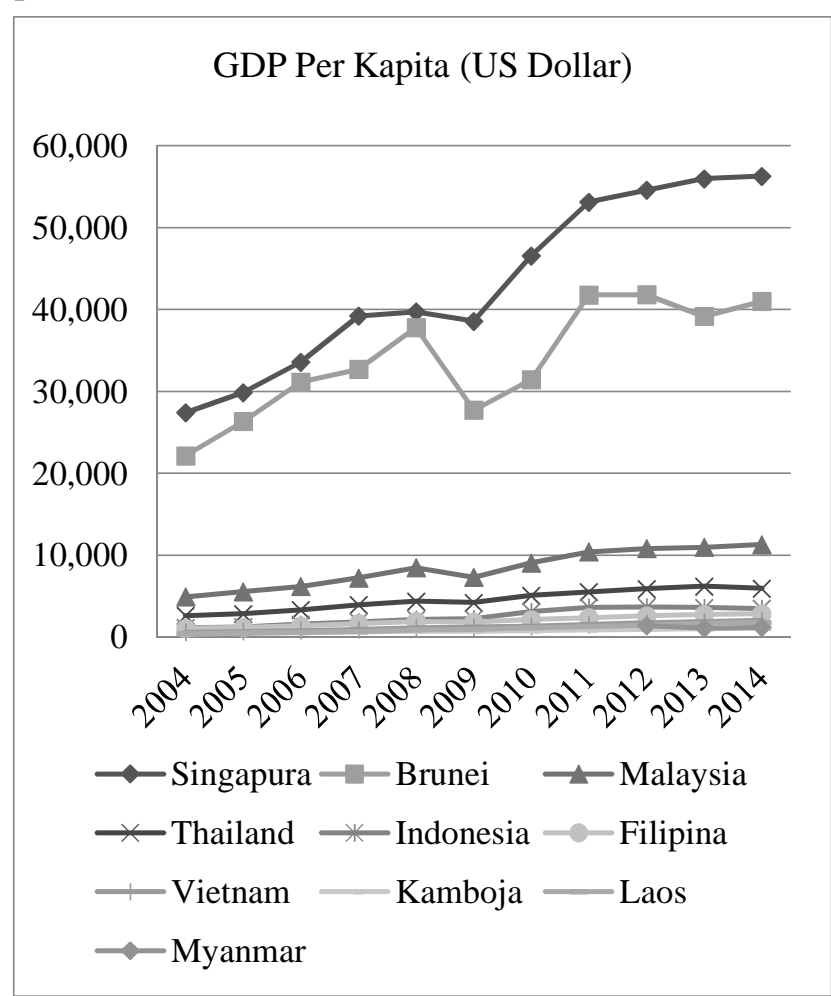

Gambar 2. GDP Per Kapita Negara ASEAN Tahun 2004-2014 (Worldbank, 2014)

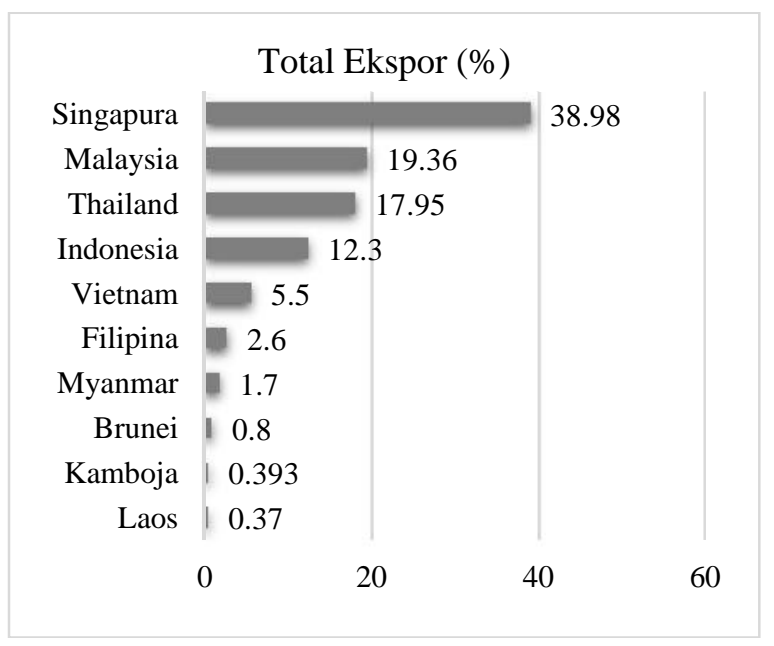

Gambar 3. Nilai Total Ekspor Negara ASEAN Tahun 2013 (ASEAN Trade Statistics Database, 2015) 


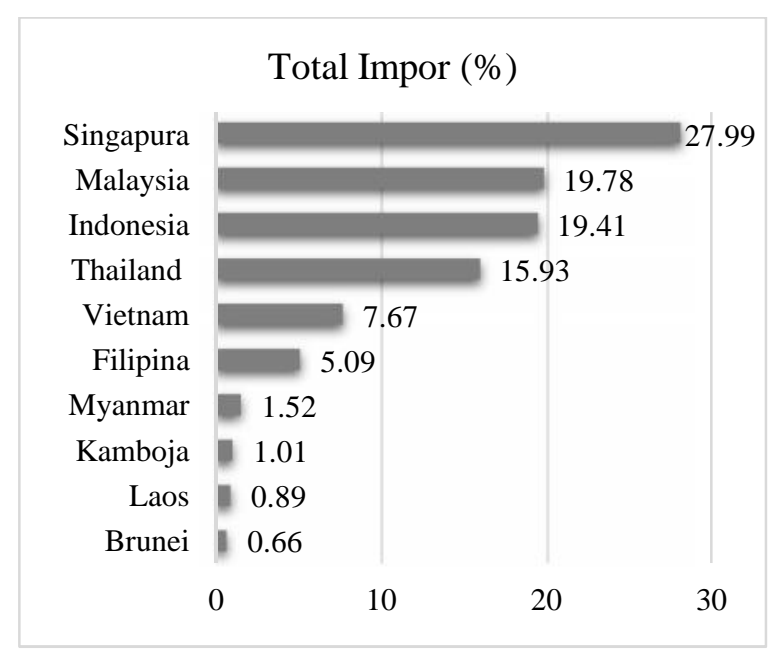

Gambar 4. Nilai Total Ekspor Dan Impor Negara ASEAN Tahun 2013 (ASEAN Trade Statistics Database, 2015)

Berdasarkan data yang dipaparkan pada Gambar 3 dan 4 dapat dilihat bahwa Singapura merupakan negara eksportir sekaligus importir terbesar ke sesama negara ASEAN yang memiliki persentase sebesar 38,98 \% untuk ekspor dan 27,99 \% untuk impor, kemudian diikuti oleh Malaysia yang memiliki persentase sebesar 19,36 \% untuk ekspor dan 19,78 \% untuk impor. Sedangkan Indonesia memiliki nilai yang lebih kecil pada sisi ekspor daripada Thailand namun berbalikan dalam hal impor. Gambar 3 juga menunjukkan bahwa kegiatan perdagangan di ASEAN hanya didominasi oleh beberapa negara saja. Hal tersebut dibuktikan berdasarkan persentase ke empat negara tersebut yang mencapai $83,13 \%$ dari segi impor dan sebesar $88,61 \%$ dari segi ekspor.

\subsection{Ekspor Kopi Indonesia ke Negara ASEAN}

Indikator perdagangan suatu negara dapat dilihat dari sejauh mana negara tersebut dapat melakukan ekspor berdasarkan keunggulan komparatif yang dimilikinya. Indonesia yang memiliki populasi tertinggi di ASEAN memiliki keunggulan komparatif dimana berlimpahnya tenaga kerja yang dapat meningkatkan produksi suatu negara. Komoditas kopi merupakan suatu komoditas yang selain membutuhkan lahan tetapi juga membutuhkan tenaga kerja sebagai faktor produksinya, sehingga ketersediaan tenaga kerja juga akan mempengaruhi terhadap produksi kopi.

Kopi merupakan komoditas unggulan Indonesia yang memiliki nilai ekspor cukup besar. Hal tersebut tidak lain dikarenakan produksi kopi Indonesia yang berlimpah dan saat ini Indonesia telah menempati peringkat ketiga di dunia sebagai negara pengekspor kopi terbesar di dunia di bawah Brazil dan Vietnam. Dengan demikian maka Indonesia menempati urutan kedua sebagai negara pengekspor kopi terbesar di dunia yang berasal dari Asia Tenggara. Berdasarkan laporan Kementerian Perdagangan (2016), setiap tahunnya ekspor kopi Indonesia ke dunia selalu meningkat, dalam kurun waktu tahun 2010 hingga tahun 2014, trend ekspor kopi Indonesia telah mengalami peningkatan sebesar 6 $\%$. Adapun pertumbuhan ekspor kopi Indonesia ke negara tujuan sejak tahun 2008 hingga tahun 2013 dipaparkan pada Gambar 5. dan sebagai pembanding, pertumbuhan ekspor kopi Vietnam dipaparkan pada Gambar 6.

\section{Pertumbuhan Ekspor Kopi Indonesia (\%)}

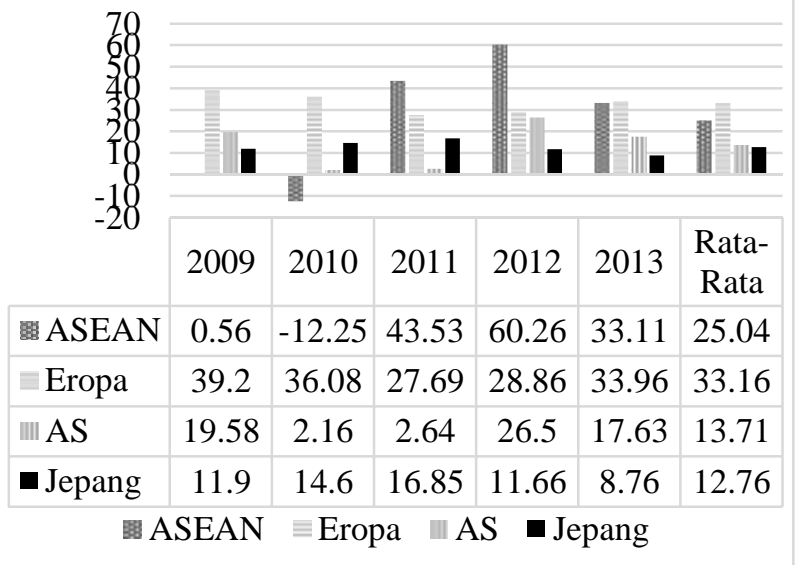

Gambar 5. Pertumbuhan Ekspor Kopi Indonesia ke Negara Tujuan Tahun 2008- 2013 (Trademap, 2015)

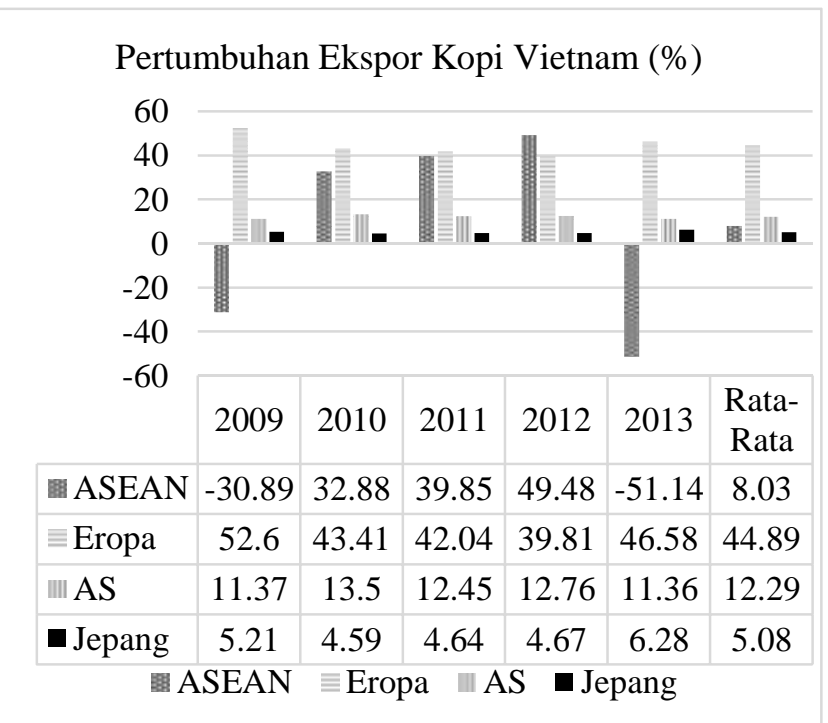

Gambar 6. Pertumbuhan Ekspor Kopi Vietnam ke Negara Tujuan Tahun 2008-2013 (Trademap, 2015) 
Berdasarkan Gambar 5. dan Gambar 6., dapat terlihat bahwa pertumbuhan ekspor kopi Indonesia dalam lima tahun terakhir mengalami peningkatan yang signifikan ke Eropa dengan nilai rata-rata pertumbuhan mencapai 33,16\% dan diikuti oleh ekspor kopi Indonesia ke ASEAN yang mencapai $25,04 \%$. Sedangakan Vietnam sebagai negara pembanding juga memiliki pertumbuhan ekspor kopi yang meningkat dalam kurun waktu lima tahun terakhir. Pertumbuhan yang signifikan adalah ekspor kopi Vietnam ke Eropa yang mencapai 44,89\% dan diikuti oleh ekspor kopi Vietnam ke AS yang mencapai $12,29 \%$, sedangkan pertumbuhan ekspor kopi Vietnam ke ASEAN hanyalah sebesar $8,03 \%$. Jika dilihat berdasarkan data tersebut, maka terlihat bahwa pertumbuhan ekspor kopi Indonesia ke ASEAN lebih tinggi jika dibandingkan dengan pertumbuhan ekspor kopi Vietnam ke ASEAN. Hal tersebut mengindikasikan bahwa kopi Indonesia semakin diminati di ASEAN sehingga trend ekspor yang terjadi pun menjadi positif. Namun demikian, hal tersebut tidak dapat mengindikasikan bahwa Indonesia menguasai pasar kopi yang ada di ASEAN. Hal ini dibuktikan dari data mengenai share pasar ekspor di ASEAN yang masih dikuasai oleh Vietnam. Dalam kurun waktu empat tahun terakhir yaitu tahun 2010 hingga tahun 2014, rata-rata share ekspor kopi Indonesia ke ASEAN hanya sebesar 25,07 \% dan masih tertinggal oleh Vietnam yang telah mencapai $38,30 \%$. Tingginya share ekspor kopi Vietnam dan Indonesia ke ASEAN ternyata didominasi oleh jenis kopi HS 090111 atau kopi yang merupakan kopi green beendan belum dilakukan proses terhadapnya seperti proses pemanggangan (not roastted) ataupun proses penghilangan kandungan kafein pada kopi (not decaffeinatted). Hal ini terlihat dari jumlah kopi yang diekspor oleh kedua negara tersebut dominan yang berjenis HS 090111, bahkan dalam kurun waktu dua tahun terakhir yaitu tahun 2012 dan 2013, rata-rata ekspor kopi jenis HS 090111 Vietnam ke ASEAN mencapai 44,74 \% dan Indonesia mencapai 35,58 \%. Oleh sebab itu, penelitian yang dilakukan berfokus pada kopi jenis HS 090111 karena merupakan kopi yang paling diminati di ASEAN.

\subsection{Daya Saing Kopi Indonesia dan Vietnam ke ASEAN}

Daya saing ekspor suatu negara dapat dilihat dari sejauh mana negara tersebut memiliki keunggulan komparatif terhadap suatu produk dimana keunggulan komparatif tersebut merupakan kemampuan suatu negara untuk memproduksi suatu produk dengan harga yang lebih rendah dibandingkan dengan negara lain. Keunggulan komparatif akan mempengaruhi faktor produksi sehingga akan membuat produksi yang dihasilkan melimpah. Produksi yang berlebih terhadap suatu produk di suatu negara akan menstimulus sebuah negara melakukan ekspor, terlebih jika harga dunia produk tersebut lebih mahal daripada harga di dalam negeri dan konsumsi domestik yang cenderung tetap. Berdasarkan data yang diperoleh dari International Coffee Organization (2016), konsumsi domestik terhadap kopi Indonesia memiliki trend yang meningkat, namun dengan persentase setiap tahunnya yang tidak menentu. Sejak tahun 2007 hingga tahun 2011, peningkatan konsumsi domestik kopi Indonesia cenderung stagnan namun pada tahun 2012 dan tahun 2013, konsumsi domestik kopi Indonesia meningkat masing-masing sebesar $10,02 \%$ dan $13,63 \%$ dan pada tahun 2014 hingga tahun 2015 kembali stagnan dengan persentase mencapai 0 $\%$.

Terus meningkatnya ekspor suatu produk, tentu akan mampu meningkatkan daya saing produk itu sendiri karena hal itu berarti bahwa produk yang di produksi di dalam negeri diminati pasar. Sejauh ini, Indonesia dan Vietnam merupakan negara yang memiliki keunggulan komparatif terhadap produk kopi. Hal tersebut menyebabkan produksi kopi yang ada di Indonesia dan Vietnam menjadi berlimpah, bahkan saat ini Indonesia dan Vietnam termasuk sebagai tiga besar eksportir kopi di dunia. Perkembangan produksi kopi di Indonesia dan Vietnam sangat mempengaruhi terhadap besaran ekspor yang dilakukan. Semakin besar suatu negara memproduksi kopi maka besar pula ekspor yang dilakukan. Namun demikian, hal tersebut hanya berlaku untuk melihat keseluruhan ekspor yang terjadi. Ekspor ke wilayah tertentu dapat menurun meskipun total produksi yang dihasilkan oleh negara pengekspor mengalami peningkatan. Hal tersebut erat kaitannya dengan permintaan terhadap kopi di wilayah tersebut dalam waktu tertentu.

Tingginya produksi kopi yang dihasilkan oleh Indonesia dan Vietnam menjadikan keduanya mengandalkan kopi sebagai andalah ekspor. Eskpor yang dilakukan tentu dapat meningkatan GDP dari masing-masing negara jika dilihat dari pendekatan pengeluaran karena besarnya kuantitas ekspor akan mempengaruhi 
terhadap nilai ekspor itu sendiri. Berdasarkan data yang diperoleh dari Trademap (2016), ekspor kopi Indonesia ke dunia telah mencapai US\$ 534 juta pada tahun 2013 dan sebesar US\$ 181 juta untuk ekspor ke ASEAN. Sedangkan Vietnam telah menghasilkan nilai ekspor mencapai US\$ 2,5 miliar ke seluruh dunia dan sebesar US\$ 135 juta ke ASEAN di tahun yang sama. Data tersebut memperlihatkan bahwa ekspor kopi Indonesia ke ASEAN tahun 2013 lebih besar daripada ekspor kopi Vietnam ke ASEAN. Hal tersebut dikarenakan turunnya produksi kopi di Vietnam dan Vietnam lebih memilih untuk melakukan ekspor ke wilayah lain seperti Eropa dan Amerika Serikat yang memiliki harga jual lebih tinggi.

Tingginya nilai ekspor kopi Indonesia dan Vietnam ke ASEAN ternyata didominasi oleh jenis kopi HS 090111 (not roastted dan not decaffeinatted) dan memiliki nilai ekspor yang besar (lebih dari US\$ 10 juta) hanya ke lima negara di ASEAN yaitu Filipina, Indonesia, Malaysia, Singapura, Thailand dan Vietnam. Hal tersebut terlihat pada Gambar 6. yang menyajikan data tentang ekspor kopi Indonesia dan Vietnam ke ASEAN 5.

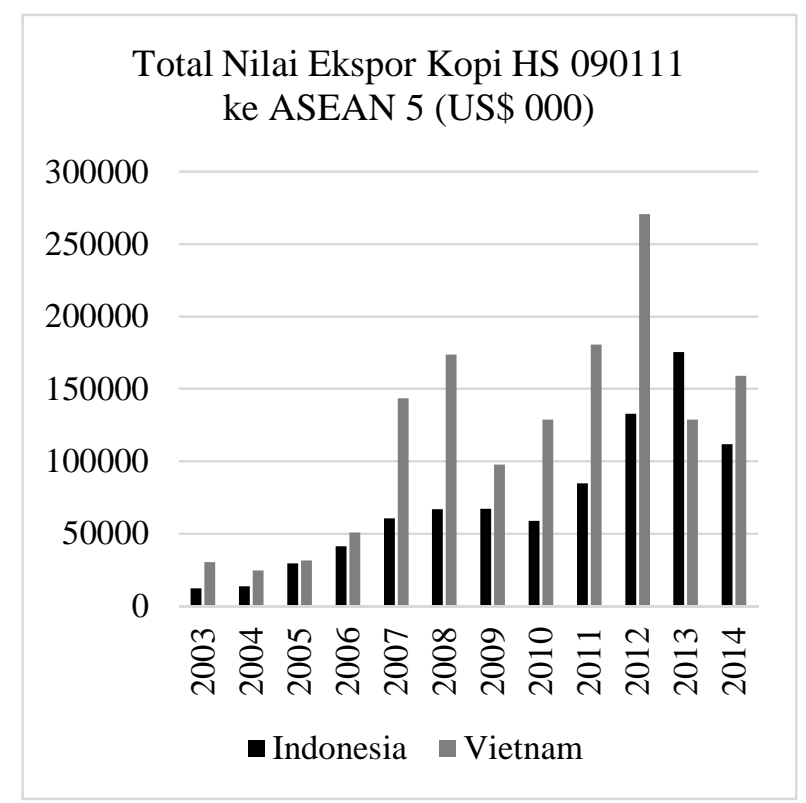

Gambar 7. Total Nilai Ekspor Kopi HS 090111 ke ASEAN 5 Tahun 2003-2014 (COMTRADE, 2016)

Berdasarkan Gambar 7, dapat terlihat bahwa nilai ekspor kopi jenis HS 090111 mengalami trend yang meningkat sejak tahun 2003 hingga tahun 2013. Hal ini mangasumsikan bahwa kopi jenis HS 090111 mendapat respon yang baik di ASEAN. Data tersebut juga mencerminkan bahwa Vietnam merupakan negara yang sangat mendominasi perdagangan kopi jenis HS 090111 di ASEAN karena di setiap tahunnya, nilai ekspor yang diterima Vietnam selalu lebih besar jika dibandingkan dengan Indonesia dan hanya pada tahun 2013 saja dimana nilai ekspor Indonesia lebih besar dari Vietnam. Hal tersebut memang dikarenakan turunnya nilai ekspor Vietnam secara keseluruhan dan bukan hanya ke ASEAN.

\section{a. Analisis Revealed Comparative Advantage (RCA)}

Kinerja perdagangan suatu negara dapat dilihat dari sejauah mana negara tersebut memiliki suatu keunggulan komparatif terhadap suatu produk. Keunggulan komparatif suatu negara terhadap suatu produk dan posisi daya saing di pasar tujuan eskpornya dapat diukur dengan menggunakan alat analisis Revealed Comparative Advantage (RCA). RCA mengukur share ekspor komoditi suatu negara dibandingkan dengan share ekspor komoditi dunia di pasar tujuan ekspor yang sama. Hasil pengukuran tersebut akan menampilkan nilai yang berkisar antara nol hingga tidak terhingga dimana suatu negara dianggap memiliki daya saing apabila memperoleh nilai di atas satu. Semakin tinggi nilai RCA maka mencerminkan bahwa daya saing yang dimiliki semakin baik. Sebaliknya, jika nilai yang diperoleh adalah di bawah satu, maka dapat dikatakan bahwa komoditas yang diukur tersebut tidak memiliki daya saing.

Hasil analisis menunjukkan bahwa produk kopi Indonesia kenis HS 090111 memiliki daya saing di pasar ASEAN. Hal tersebut didasarkan pada hasil pengukuran RCA yang menunjukkan bahwa nilai RCA yang dimiliki Indonesia berada pada nilai lebih dari satu. Namun demikian, nilai RCA yang dimiliki Indonesia tidak lebih tinggi dari yang dimiliki Vietnam. Hal tersebut menandakan bahwa kopi jenis HS 090111 yang diekspor Indonesia telah mendapat apresiasi namun masih kalah saing dari produk yang diekspor oleh Vietnam.

Berdasarkan nilai RCA yang dipaparkan pada Tabel 3. dan Tabel4., dapat dilihat secara spesifik perbandingan nilai RCA produk kopi jenis HS 090111 antara Indonesia dan Vietnam dari tahun 2001 hingga tahun 2014. Secara garis besar dapat dikatakan bahwa kopi Vietnam lebih memiliki daya saing daripada produk asal Indonesia. Secara rata-rata, produk kopi Indonesia jenis HS 090111 hanya unggul di atas Vietnam pada pasar ekspor Thailand. 
Tabel 1. Nilai RCA (Revealed Comparative Advantage) Produk Kopi Indonesia Jenis HS 090111 ke ASEAN 5 Tahun 2001-2014

\begin{tabular}{ccccccc}
\hline \multirow{2}{*}{ Tahun } & \multicolumn{6}{c}{ Negara Tujuan } \\
\cline { 2 - 7 } 2001 & 2,95 & 13,75 & 30,07 & 13,81 & 0,21 & 12,15 \\
2002 & 3,68 & 13,92 & 31,97 & 331,50 & 0 & 12,56 \\
2003 & 2,81 & 9,8 & 13,53 & 112,35 & 0,27 & 8,12 \\
2004 & 1,05 & 9,83 & 13,20 & 143,81 & 0,87 & 9,92 \\
2005 & 4,35 & 7,88 & 20,48 & $66,82 *$ & $6,57 *$ & 13,56 \\
2006 & 20,91 & 5,77 & 21,92 & 2,41 & 2,95 & 14,15 \\
2007 & 11,32 & 6,35 & 17,68 & 3,22 & $1,45 *$ & 8,61 \\
2008 & 12,94 & 7,80 & 15,44 & 0,03 & $2,27 *$ & 10,51 \\
2009 & 10,17 & 6,58 & 16,26 & 11,98 & 9,07 & 11,20 \\
2010 & 3,78 & 6,25 & 13,74 & 8,84 & 3,26 & 7,43 \\
2011 & 1,16 & 5,88 & 11,42 & 3,70 & 2,75 & 5,76 \\
2012 & 6,63 & 7,07 & 13,85 & 0,91 & 9,93 & 7,83 \\
2013 & 6,37 & 7,51 & 15,49 & 28,10 & 12,57 & 12,53 \\
2014 & 6,92 & 6,10 & 15,32 & 7,39 & 11,50 & 7,93 \\
Rata- & 6,79 & 8,18 & 17,88 & 52,49 & 4,55 & 10,16 \\
\hline rata & & & & & & \\
\cline { 2 - 7 }
\end{tabular}

*) Data Estimasi

Tabel 2. Nilai RCA (Revealed Comparative Advantage) Produk Kopi Vietnam Jenis HS 090111 ke ASEAN 5 Tahun 2001-2014

\begin{tabular}{|c|c|c|c|c|c|c|}
\hline \multirow{2}{*}{ Tahun } & \multicolumn{6}{|c|}{ Negara Tujuan } \\
\hline & Filipina & Malaysia & Singapura & Thailand & Indonesia & ASEAN5 \\
\hline 2001 & 62,23 & 36,03 & 51,65 & 0 & 45,42 & 40,44 \\
\hline 2002 & 103,14 & 44,83 & 68,49 & 0 & 33,25 & 74,00 \\
\hline 2003 & 109,87 & 69,00 & 103,63 & 0,35 & 6,93 & 91,82 \\
\hline 2004 & 79,31 & 53,52 & 56,29 & 0,32 & 5,63 & 59,23 \\
\hline 2005 & 48,81 & 26,37 & 30,86 & 0,13 & 23,11 & 51,32 \\
\hline 2006 & 50,88 & 41,15 & 50,29 & 0,02 & 48,68 & 52,09 \\
\hline 2007 & 43,38 & 38,66 & 52,15 & 134,69 & 54,02 & 62,87 \\
\hline 2008 & 19,03 & 27,24 & 195,68 & 126,13 & 48,79 & 66,91 \\
\hline 2009 & 17,65 & 27,66 & 124,29 & 50,56 & 99,40 & 51,35 \\
\hline 2010 & 26,68 & 24,33 & 218,18 & 98,64 & 46,47 & 57,86 \\
\hline 2011 & 37,68 & 19,60 & 147,56 & 48,71 & 46,87 & 47,78 \\
\hline 2012 & 24,22 & 11,23 & 45,48 & 76,63 & 62,54 & 42,75 \\
\hline 2013 & 28,91 & 7,00 & 3,24 & 19,34 & 51,28 & 21,63 \\
\hline 2014 & 23,84 & 13,54 & 6,33 & 45,17 & 45,63 & 28,07 \\
\hline $\begin{array}{c}\text { Rata- } \\
\text { rata }\end{array}$ & 48,26 & 31,44 & 82,44 & 42,91 & 44,14 & 53,44 \\
\hline
\end{tabular}

Hal tersebut dimungkinkan terjadi karena nilai RCA Indonesia pada pasar ekspor Vietnam sangat tinggi pada kurun waktu tahun 2001 hingga tahun 2005, namun setelah itu nilai RCA kopi Indonesia selalu lebih rendah jika dibandingkan oleh Vietnam.

\section{b. Analisis Export Product Dynamics (EPD)}

Daya saing suatu produk di pasar tujuan ekspor dapat diukur dengan alat analisis selain RCA (Revealed Comparative Advantage), yaitu analisis Export Product Dynamics (EPD). Metode ini digunakan untuk menangkap gambaran umum suatu perdagangan dimana dapat terlihat tingkat kedinamisan pertumbuhan ekspor pada suatu peridoe tertentu yang nantinya akan dikelompokan menjadi 4 indikator yaitu rising star, falling star, lost opportunity dan retreat.

Data yang digunakan untuk melakukan analisis ini adalah data ekspor kopi jenis HS 090111 yang dihimpun dari COMTRADE dan Trademap tahun 2001 hingga tahun 2014. Hasil analisis EPD menunjukan bahwa Indonesia maupun Vietnam berada pada kuadran rising star yang berarti bahwa kinerja perdagangan ekspor berjalan cepat dan dinamis dimana tingkat pertumbuhan ekspor Indonesia terus meningkat seiring dengan meningkatnya pangsa ekspor kopi di ASEAN 5. Berikut adalah posisi ekspor kopi jenis HS 090111 Indonesia dan Vietnam menurut matriks EPD:

Tabel 3. Sumbu X dan Sumbu Y Matriks Export Product Dynamics EPD) kopi jenis HS 090111 Indonesia dan Vietnam

\begin{tabular}{|c|c|c|}
\hline EPD & Indonesia & Vietnam \\
\hline $\mathrm{x}$ & 0,026170315 & 0,06023405 \\
\hline $\mathrm{y}$ & 0,012515082 & 0,05369746 \\
\hline
\end{tabular}

Matriks EPD Kopi Jenis HS 090111 Indonesia dan Vietnam

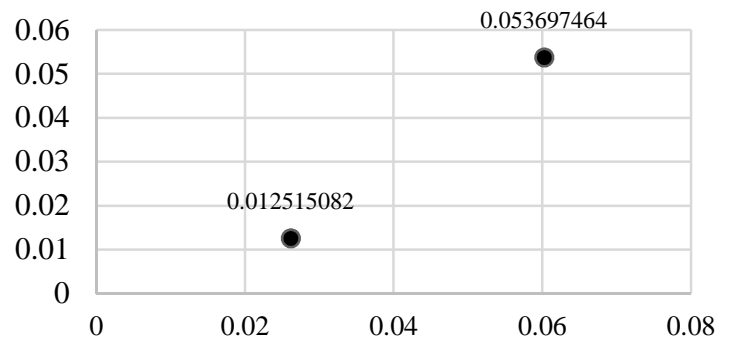

Gambar 8. Matriks Export Product Dynamics (EPD) kopi jenis HS 090111 Indonesia dan Vietnam 


\section{Kesimpulan}

Mengacu pada tujuan penelitian serta pembahasan dari hasil penelitian yang telah dilakukan maka terdapat beberapa kesimpulan yang dapat ditarik antara lain adalah bahwa pasar ekspor kopi jenis HS 090111 (Coffee, not roasted, not decaffeinated) memiliki potensi yang besar jika di perdagangkan di pasar ASEAN 5. Hal tersebut didasarkan pada kenyataan bahwa tingginya nilai ekspor dari kedua negara ke negara ASEAN 5 tersebut dan terus bertumbuh setiap tahunnya.

Berdasarkan perhitungan nilai RCA (Revealed Comparative Advantage), ekspor kopi Indonesia jenis HS 090111 memiliki daya saing di pasar ASEAN 5 meskipun nilai RCA yang didapat tidak lebih tinggi dari yang dimiliki oleh Vietnam. Dalam kurun waktu 15 tahun terakhir (2001-2014), rata-rata RCA yang diperoleh Indonesia di pasar ASEAN 5 adalah sebesar 10,16 sedangkan Vietnam sebesar 53,44. Negara yang memiliki nilai RCA terbesar dari ekspor kopi Indonesia adalah Thailand dengan nilai sebesar 52,49. Namun hal tersebut tidak dapat dijadikan sebuah acuan mengingat nilai RCA Indonesia ke Thailand memiliki nilai yang besar hanya di kurun waktu tahun 2001 hingga tahun 2005. Hal ini dikarenakan Thailand juga merupakan negara pengekspor kopi yang menyebabkan impor kopi Thailand tidak terlalu besar, ditambah lagi bahwa kopi di Thailand bukan menjadi komoditas utama sehingga nilai impor kopi Thailand akan sulit diprediksi.

Secara keseluruhan, dapat dikatakan bahwa ekspor produk kopi jenis HS 090111 milik Vietnam lebih berdaya saing jika dibandingkan dengan produk dari Indonesia di pasar ASEAN 5 dan berdasarkan analisis matriks EPD yang digunakan pada penelitian menunjukkan bahwa perdagangan kopi Indonesia maupun Vietnam berada pada kuadran rising star yang berarti bahwa kinerja perdagangan ekspor berjalan cepat dan dinamis dimana tingkat pertumbuhan ekspor Indonesia terus meningkat seiring dengan meningkatnya pangsa eskspor kopi di pasar ASEAN. Hal tersebut juga menegaskan bahwa kondisi perdagangan kopi Indonesia dan Vietnam di pasar ASEAN 5 telah berjalan dengan baik dan memiliki daya saing yang tinggi meskipun perdagangan kopi tersebut lebih didominasi oleh kopi dari Vietnam daripada Indonesia.

\section{Daftar Pustaka}

[1]. ASEAN Trade Statistics Database. 2015. ASEAN Statistical Yearbook. The ASEAN Secretariat. Jakarta.

[2]. Aquino A. 1981. Change Over Time in The Pattern of Comparative Advantage In Manufactured Goods: An Empirical Analysis For The Period 1972-1974. European Economic Review. Vol. 15, pp. 41-62.

[3]. Basri F, Munandar H. 2010. DasardasarEkonomiInternasional.

PengenalandanAplikasiMetodeKuantitatif.

EdisiPertama. Jakarta

:KencanaPrenada Media Group.

[4]. Crafts NFR. and Thomas M. 1986. Comparative Advantage in Uk Manufacturing Trade, 1910-1935. Economic journal. Vol. 96 No. 383, pp. 629-45.

[5]. Hadi P.U, Mardianto S. 2004. Analisis Komparasi Daya Saing Produk Ekspor Pertanian Antar Negara ASEAN Dalam Era Perdagangan Bebas AFTA. Jurnal Agro Ekonomi Vol 22. No.1. Jakarta.

[6]. Estherhuizen D. 2006. Measuring and Analyzing Competitiveness in the Agribusiness Sector: Methodological and Analytical Framework. Pretoria: University of Pretoria.

[7]. Hillman AL. 1980. Observation on The Relation Between Revealed Comparative Advantage and Comparative Advantage as Indicated by Pre-Trade Relative Prices. Weltwirtschaftliches Archiv. Vol. 116, pp. 315-21.

[8]. International Coffee Organization (ICO). 2015. Exporting Countries: Total Production. Available at http://www.ico.org/prices/po.htm. (Diakses 19 Des 2015).

[9]. Kementerian Perdagangan. 2015. Neraca perdagangan Indonesia total. http://www.kemendag.go.id/id/economicprofile/indonesia-export-import/indonesiatrade-balance (Diakses Mei 2015).

[10]. Laursen K. 1998. Revealed Comparative Advantage and The Alternatives as Measures Of International Specialisation. DRUID Working Paper No. 98-30. 
[11]. Lee J. 1995. Comparative Advantage in Manufacturing As a Determinant of Industrialization, The Korean Case. World Development. Vol. 23 No. 7, pp. 1195214.

[12]. Li KW, Bender S. 2002. The Gain And Loss In Export Advantage Among World Regions. Discussion Paper No. 853.

[13]. Lim KT. 1997. Analysis Of North Korea's Foreign Trade By Revealed Comparative Advantage. Journal of Economic Development. Vol. 22, pp. 97-117.

[14]. Marchese S, De Simone FN. 1989. Monotonicity of Indices of Revealed Comparative Advantage: Empirical Evidence on Hillman's Condition. Weltwirtschaftliches Archiv. Vol. 125, pp. 158-67.

[15]. Parry GT. 1975. Trade and Non-Trade Performance of Us Manufacturing Industry: Revealed Comparative Advantage. The Manchester School Of Economics and Social Studies. Vol. 43 No. 2, pp. 158-72.

[16]. Rana PB. 1990. Shifting Comparative Advantage Among Asian and Pacific Countries. The International Trade Journal. Vol. 4 No. 3, pp. 243-58.

[17]. Richardson JD, Feketekuty G, Zhang C, Rodriguez AE. 1997. US Performance And Trade Strategy In A Shifting Global Economy In Feketekuty, G, Stokes, B. (Eds), Trade Strategies For A New Era: Ensuring US Leadership in a Global Economy. New York: Council on Foreign Relations Press.

[18]. Trade Map, 2015. Trade Statistics for International Business Development. http://www.trademap.org/Index.aspx (Diakses Mei 2015).

[19]. Van Hulst, N, Mulder R. and Soete LLG. 1991. Exports And Technology In Manufacturing Industry. Weltwirtschaftliches Archiv. Vol. 127, pp. 246-64.

[20]. World Bank, 2014. GDP per capita. Available at http://data.worldbank.org/indicator/NY.G DP.PCAP.CD (Diakses 25 Februari 2016).
[21]. Yang YZ. 1999. China's Textile And Clothing Exports: Changing International Comparative Advantage and Its Policy Implication. Working paper. Asia pacific school of economics and management.

[22]. Yeats AJ. 1985. OnThe Appropriate Interpretation of The Revealed Comparative Advantage Index: Implications Of A Methodology Based On Industry Sector Analysis. WeltwirtschaftlichesArchiv. Vol. 121, pp. 61-73. 